\title{
Evidence Summary: Octenidine for chronic wounds
}

January 2020

Author: Assoc. Prof. Emily Haesler, PhD

Wound Healing and Management Unit, Curtin University (WHAM@Curtin)

For referencing Haesler E. Evidence Summary: Octenidine for chronic wounds. Wound Practice and Research 2020; 28(1):42-44.

DOI https://doi.org/10.33235/wpr.28.1.42-44

\section{CLINICAL QUESTION}

What is the best available evidence for using octenidine (OCT) products to reduce infection and promote healing in chronic wounds in all populations?

\section{SUMMARY}

Octenidine dihydrochloride (OCT) is an antiseptic that has been used as a wound treatment for over 20 years. ${ }^{1}$ Level 5 bench research ${ }^{2,3}$ indicates that OCT products have broad-spectrum antimicrobial activity against gram positive and negative bacteria, fungus and methicillinresistant Staphylococcus aureus [MRSA]. Level $1^{4}$ and Level $2^{5,6}$ clinical trials demonstrate antimicrobial efficacy of OCT when used to treat chronic wounds, particularly venous leg ulcers (VLUs). Efficacy of OCT in promoting complete wound closure or reduction in wound surface over a 4 to 12 week period for VLUs was demonstrated in four small Level $1^{7,8}$ and Level $2^{5,6}$ studies. Evidence from four Level 4 studies $^{9-12}$ conducted in other chronic wound types also established that OCT is associated with positive wound healing outcomes. This evidence supported a Grade $B$ recommendation (a weak recommendation). ${ }^{13}$

\section{CLINICAL PRACTICE RECOMMENDATIONS}

All recommendations should be applied with consideration to the wound, the patient, the health professional and the clinical context.

Octenidine-based products could be used to reduce local infection and promote healing in chronic wounds. (Grade B).
This summary was conducted using methods published by the Joanna Briggs Institute..$^{13-15}$ The summary is based on a literature search combining search terms related to OCT and chronic wound types. Searches were conducted in CINAHL, Medline, the Cochrane Library and Google Scholar for evidence published up to December 2019 in English. Levels of evidence for intervention studies are reported in the table below $(1=$ high $)$.

\section{BACKGROUND}

Octenidine dihydrochloride is a surfactant solution. When used in wound care, surfactants reduce the surface tension between the liquid and the skin surface, which increases the ability of the solution to wet the wound bed by spreading further and accessing wound pockets. ${ }^{9,18,19}$ Octenidine is available as an irrigation solution or as a gel designed to promote autolytic debridement.9,18 Laboratory studies have demonstrated efficacy of OCT in reducing bacteria and fungi, ${ }^{2,3}$ eradicating bacterial biofilm ${ }^{19}$ and controlling newly forming biofilm for up to 72 hours. ${ }^{19}$ Onset of antimicrobial activity is reported as within 3 to 10 hours, and due to its non-antimicrobial specific effect, resistance does not develop ${ }^{17}$ (all Level 5). An RCT conducted in acute wounds (skin graft donor sites) demonstrated efficacy in reducing superficial bacterial contamination within 24 hours $^{16}$ (Level 1).

\section{CLINICAL EVIDENCE}

Reduction in local infection

- In an RCT at moderate risk of bias, OCT solution used for wet-to-moist cleansing was effective in reducing

\section{SOURCES OF EVIDENCE}

\begin{tabular}{|c|c|c|c|c|}
\hline $\begin{array}{l}\text { Level } 1 \\
\text { Evidence }\end{array}$ & $\begin{array}{l}\text { Level } 2 \\
\text { Evidence }\end{array}$ & $\begin{array}{l}\text { Level } 3 \\
\text { Evidence }\end{array}$ & $\begin{array}{l}\text { Level } 4 \\
\text { Evidence }\end{array}$ & $\begin{array}{l}\text { Level } 5 \\
\text { Evidence }\end{array}$ \\
\hline Experimental Designs & $\begin{array}{l}\text { Quasi-experimental } \\
\text { Designs }\end{array}$ & $\begin{array}{l}\text { Observational - } \\
\text { Analytic Designs }\end{array}$ & $\begin{array}{l}\text { Observational - } \\
\text { Descriptive Studies }\end{array}$ & $\begin{array}{l}\text { Expert Opinion/ Bench } \\
\text { Research }\end{array}$ \\
\hline 1.c $\mathrm{RCT}^{4,7,8,16}$ & $\begin{array}{l}\text { 2.c Quasi-experimental } \\
\text { prospectively } \\
\text { controlled study } \\
\text { 2.d Pre-test - post- } \\
\text { test or historic/ } \\
\text { retrospective } \\
\text { control group } \\
\text { study }^{6}\end{array}$ & None & 4.d Case study ${ }^{9-12}$ & $\begin{array}{l}\text { 5.b Expert consenus }{ }^{17} \\
\text { 5.c Bench research }{ }^{2,3} \\
\text { and single expert } \\
\text { opinion }{ }^{1,18,19}\end{array}$ \\
\hline
\end{tabular}


bacterial burden within 20 minutes of application. Bacterial burden was reduced by a statistically significant amount (mean reduction 2.90 natural log reduction factor, $p=0.015$ ) in 23 chronic wounds. This was as effective as a range of other commonly used antiseptic solutions $^{4}$ (Level 1).

- In the pre-experimental washout period of a quasiexperiment at moderate risk of bias, microbiological assessment of VLUs $(n=50)$ irrigated with OCT for four weeks showed complete eradication of gram-positive and gram-negative bacteria (including MRSA) in $88 \%$ of wounds and large reductions in number of bacterial strains in the remaining wounds $(p<0.05)^{6}$ (Level 2$)$.

- In a quasi-experiment at high risk of bias conducted in chronic venous leg ulcers (VLUs, $n=49$ ), clinical signs of local infection did not significantly differ between VLUs treated with silver dressings and those treated with OCT gel either with $(p=0.0117)$ or without $(p=0.213)$ a woundphase adapted modern dressing, suggesting OCT is as effective as silver in reducing bacterial bioburden ${ }^{5}$ (Level 2).

\section{Improvement in wound healing outcomes}

- In an RCT at low risk of bias, there was no significant difference in rate of complete closure within 12 weeks of chronic VLUs $(n=99)$ for those treated with OCT compared to Ringer's solution $(p=0.882)$. When analysis was limited to larger VLUs that had persisted more than six months $(n=28)$, significantly more VLUs treated with OCT achieved complete healing compared to Ringer's solution $(33.3 \% \text { versus } 0 \%, p=0.022)^{7}$ (Level 1).

- An RCT at moderate risk of bias conducted in nonhealing VLUs $(n=76)$ demonstrated superiority in mean percent reduction in wound surface area for an OCT layered dressing compared to a silver dressing (OCT $1.58 \pm 0.77 \mathrm{~cm}^{2} /$ week versus silver, $0.23 \pm 0.88 \mathrm{~cm}^{2} /$ week, $\mathrm{p}=0.0182$ ). This amounted to an average size reduction of $58 \%$ for OCT and $14 \%$ for silver dressings ${ }^{8}$ (Level 1).

- Chronic VLUs treated with OCT gel achieved $96.2 \%$ reduction in wound size at 42 days, compared with $64.1 \%$ reduction for VLUs treated with OCT gel in combination with a wound-phase adapted modern dressing and compared with $14.6 \%$ for VLUs treated with silver dressings ${ }^{5}$ (Level 2).

- In the four-week wash out observational period of a study comparing different dressings, all VLUs $(n=50)$ were irrigated with OCT and received a basic dressing. Over time, there was a significant improvement in VLUs with respect to necrotic tissue $(p<0.0001)$, granulation tissue $(p=0.0003)$ and epithelialisation $(p<0.0001)^{6}$ (Level 2).

- In a small number of case studies at high risk of bias, OCT irrigation (often used in combination with an OCT gel) was associated with a reduction in slough and an increase in granulating tissue and epithelialisation for chronic wounds of different aetiologies ${ }^{9-12}$ (Level 4).

\section{CONSIDERATIONS FOR USE}

The following points could be considered when using OCT products in wound management:

- Octenidine might assist in managing comfort and wound pain. In one RCT an OCT layered dressing was associated with superior pain management compared to silver dressings ${ }^{8}$ (Level 1) and in a small number of case reports, OCT-soaked gauze was associated with reduced moderate pain after two weeks of treatment ${ }^{9}$ (Level 4). In another study ( $n=50)$, there was a statistically significant $(p<0.05)$ reduction in VLU pain after four weeks' of irrigation with OCT ${ }^{6}$ (Level 2). In a quasi-experiment, individuals with VLUs receiving an OCT gel dressing described the treatment as pleasantly cooling, but satisfaction was not significantly greater than for a silver dressing ${ }^{5}$ (Level 2).

- Octenidine appears to have a good safety profile. No significant side effects were reported in the studies included in this evidence summary. In one RCT, OCT was associated with fewer adverse events than Ringer solution (16.7\% versus $18.8 \%)$ and no participants receiving OCT experienced a serious side-effect ${ }^{7}$ (Level 1).

- Octenidine products might be more cost-effective than other wound treatment options. A quasi-experiment conducted in 49 VLUs indicated that OCT gel was a cost-effective treatment compared to using silver dressings ${ }^{5}$ (Level 2).

- Follow the manufacturer's direction when selecting OCT products for wound irrigation or wound dressings.

\section{REFERENCES}

1. Hubner NO, Siebert J, Kramer A. Octenidine dihydrochloride, a modern antiseptic for skin, mucous membranes and wounds. Skin Pharmacol Physiol, 2010;23(5):244-58.

2. Koburger T, Hubner NO, Braun M, Siebert J, Kramer A. Standardized comparison of antiseptic efficacy of triclosan, PVP-iodine, octenidine dihydrochloride, polyhexanide and chlorhexidine digluconate. J Antimicrob Chemother, 2010. Aug;65(8):1712-9.

3. Pavlik V, Sojka M, Mazurova M, Velebny V. Dual role of iodine, silver, chlorhexidine and octenidine as antimicrobial and antiprotease agents. PLoS ONE, 2019. January;14 (1) (no pagination)(e0211055).

4. Assadian O, Kammerlander G, Geyrhofer C, Luch G, Doppler S, Tuchmann F, Eberlein T, Leaper D. Use of wet-to-moist cleansing with different irrigation solutions to reduce bacterial bioburden in chronic wounds. J Wound Care, 2018;27(Sup10):S10-S6.

5. Hämmerle G, Strohal R. Efficacy and cost-effectiveness of octenidine wound gel in the treatment of chronic venous leg ulcers in comparison to modern wound dressings. Int Wound J, 2016;13(2):182-8.

6. Sopata M, Kucharzewski M, Tomaszewska E. Antiseptic with modern wound dressings in the treatment of venous leg ulcers: clinical and microbiological aspects. J Wound Care, 2016;25(8):419-26.

7. Vanscheidt W, Harding K, Téot L, Siebert J. Effectiveness and tissue compatibility of a 12-week treatment of chronic venous leg ulcers with an octenidine based antiseptic--a randomized, double-blind controlled study. Int Wound J, 2012;9(3):316-23.

8. Krasowski G, Jawień A, Tukiendorf A, Rybak Z, Junka A, OlejniczakNowakowska M, Bartoszewicz M, Smutnicka D. A comparison of an antibacterial sandwich dressing vs dressing containing silver. Wound Repair Regen, 2015;23(4):525-30.

9. Braun $M$, Price J, Ellis $M$. An evaluation of the efficacy and cost-effectivness of octenilin ${ }^{\circledR}$ for chronic wounds. Wounds UK, 2014;10(4):89-96. 
10. Chadwick P, Ivins N, Pilcher M, Stephen-Haynes J. Case studies: Octenilin Wound Irrigation Solution and Octenilin Wound Gel in practice. Wounds UK, 2016;EWMA Special:46-53.

11. Sharpe A, Neves J, Formiga A, Serafino E, Machado M. Case studies: Octenidine in the management of diabetic foot ulcers. Diabetic Foot Journal 2018;T21(3):192-7.

12. Tapiwa Chamanga E, Hughes M, Hilston K, Sparke A, Jandrisits $\mathrm{JM}$. Chronic wound bed preparation using a cleansing solution. $\mathrm{Br} \mathrm{J}$ Nurs, 2015;24(12):S30-6.

13. Joanna Briggs Institute Levels of Evidence and Grades of Recommendation Working Party. New JBI Grades of Recommendation. Adelaide: Joanna Briggs Institute2013.

14. Aromataris E, Munn Z, editors. Joanna Briggs Institute Reviewer's Manual. https://reviewersmanual.joannabriggs.org/ The Joanna Briggs Institute; 2017.

15. The Joanna Briggs Institute Levels of Evidence and Grades of Recommendation Working Party. Supporting Document for the Joanna Briggs Institute Levels of Evidence and Grades of Recommendation. www.joannabriggs.org: The Joanna Briggs Institute2014.

16. Eisenbeiss W, Siemers F, Amtsberg G, Hinz P, Hartmann B, Kohlmann T, Ekkernkamp A, Albrecht U, Assadian O, Kramer A. Prospective, double-blinded, randomised controlled trial assessing the effect of an octenidine-based hydrogel on bacterial colonisation and epithelialization of skin graft wounds in burn patients. Int $\mathrm{J}$ Burn Trauma, 2012;2(2):71-9.

17. Kramer A, Dissemond J, Kim S, Willy C, Mayer D, Papke R, Tuchmann F, Assadian O. Consensus on Wound Antisepsis: Update 2018. Skin Pharmacol Physiol, 2018;31(1):28-58.

18. Braun M, McGrath A, Downie F. Octenilin ${ }^{\circledR}$ range made easy. Wounds UK, 2013;9(4).

19. Cutting $\mathrm{K}$, Westgate $\mathrm{S}$. The use of cleansing solutions in chronic wounds. Wounds UK 2012;8(4):130-3.

\section{Biatain}

\section{Coloplast Biatain Literary Awards}

Wound Practice \& Research, the Australian Journal of Wound Management and

Coloplast Australia are pleased to offer three Coloplast Biatain Literary Awards.

These awards are designed to encourage and reward those who publish their wound care clinical experience. The awards acknowledge excellence of original manuscripts, case presentations and clinical research undertaken within Australasia, both novice and advanced.

Each winner of the Coloplast Biatain Literary Award receives $\$ 1000$ to be used towards future endeavours in wound management. To enter you must be the first-named author of a manuscript published in Wound Practice \& Research Journal. Manuscripts must relate to a case study, original research or a literature/clinical practice review, authors are preferably members of Wounds Australia.

Judged by the Editorial Board of Wound Practice \& Research annually, one award per category is given based on published articles in the calendar year.

Coloplast manufactures Biatain, Biatain Ag, Biatain Ibu, Biatain Silicone, Biatain Silicone Lite, Biatain Super, Biatain Alginate, Comfeel Plus Transparent and Ulcer dressings which provide integrated solutions in wound healing. Coloplast Wound Care is committed to the development of excellence in wound management practices.

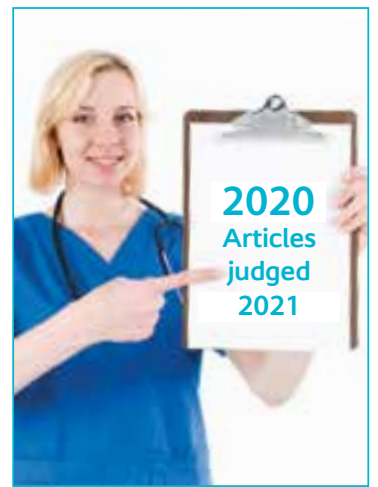

